\title{
UNDERCURRENTS IN JONAH
}

\author{
James E. Robson
}

\begin{abstract}
Summary
On the surface, the book of Jonah is marked by a certain literary simplicity and apparent artlessness. This is evident in at least three ways: its style, with few adjectives, action-oriented narrative, repetition of words and phrases, sound-plays and personifications; its plot, with extreme scenarios and a binary view of the world; its structure, with significant substantial correspondence. Yet it is often in the very places of apparent artlessness that there are hidden depths. A survey of these undercurrents suggests that the book of Jonah is best understood as an engaging exploration of how credal confessions relate to the complexities of lived experience.
\end{abstract}

\section{Introduction}

Phyllis Trible wrote in 1994, 'Jonah studies have become an industry ... Despite great waves of words stirring up storms on the sea of scholarship, Jonah refuses to be drowned." ${ }^{1}$ This article adds another drop in the ocean. It has been stimulated by an article of David Clines over twenty years ago, 'False Naivety in the Prologue to Job'. ${ }^{2}$ In that article, Clines argued that the prologue of Job, despite first appearances, is every bit as sophisticated and subtle as the dialogue. Although apparently a folk tale of artless simplicity or naivety, it is in fact something very different. 'By naivety we understand an artless

1 Phyllis Trible, Rhetorical Criticism: Context, Method, and the Book of Jonah (Guides to Biblical Scholarship: Old Testament Series; Minneapolis: Fortress, 1994): ix.

2 David J. A. Clines, 'False Naivety in the Prologue to Job', Hebrew Annual Review 9 (1985): 127-36, reprinted in On the Way to the Postmodern: Old Testament Essays 1967-1998 (2 vols.; JSOTSup 291-92; Sheffield: Sheffield Academic Press, 1998): 735-44. Subsequent references come from the reprint. 
ingenuousness, an unsubtle simplicity.' 3 For him, 'false naivety exploits the appearance of artlessness to convey a subtle message'. ${ }^{4}$

Reading through those lenses, 'its very naivety, the excess of its naivety, is what invites more thoughtful readings, and entices the reader into a participatory scrutiny of its hidden depths'. ${ }^{5}$ For Clines, this meant something close to, as he puts it, the "naivety of the prologue deconstructing itself'.

In her study in Job, Contest in Moral Imaginations, Carol Newsom notes the recent penchant for seeing the prologue of Job as 'slyly subversive', and suggests that it arises because of the postmodern dislike for authoritarian moral discourse. Such discourse privileges a view of truth that is unitary and absolute, respects figures of authority as 'the voice of truth', privileges principle above situation and 'prizes coherency'. While not denying the validity of such readings, she insists that it is also possible to read Job's prose tale 'with rather than against its generic conventions'. ${ }^{6}$

I am inclined to agree with her that there is a contemporary cultural dislike for moral discourse which conveys a message and which privileges a unitary view of truth. I am also inclined to agree with her that there is no need to see the prose tale as, in Clines's words, a 'beguilement' that either 'seduces naive readers into finding a reflection of their own shallowness in the text' or 'equally entrances more perceptive readers into an exploratory journey into its depths'?

Nonetheless, there is something important about the gap between what appears the case on the surface, and what is going on in the depths. And it is the same with the book of Jonah. ${ }^{8}$ On the surface,

3 Clines, 'False Naivety', 735.

4 Clines, 'False Naivety', 735.

5 Clines, 'False Naivety', 744.

6 Carol A. Newsom, The Book of Job: A Contest of Moral Imaginations (Oxford: Oxford University Press, 2003): 41-47. She quickly declares that her 'hospitality' is not a 'complete surrender to its claims' because her sympathetic reading takes its place within a reading of the whole as a polyphonic text.

7 Clines, 'False Naivety', 736. It should be noted that, despite the choice of verbs, Clines insists that 'False naivety is not ... an act of bad faith.'

8 Robert Alter, The Art of Biblical Narrative (London: George Allen \& Unwin, 1981): 33 connects Job and Jonah, regarding them as 'the only evident exceptions' to the uneven continuum within the Hebrew Bible of 'narratives presented as history'. More specifically R. W. L. Moberly, 'Jonah, God's Objectionable Mercy, and the Way Of Wisdom' in Reading Texts, Seeking Wisdom: Scripture and Theology, ed. David Ford and Graham Stanton (London: SCM, 2003): 157 n. 5 observes that Jonah 'is ... comparable to Job $1-2$, where also a fundamental theological issue is explored in an 
there is a certain artless simplicity. But swirling amongst the seaweed are turbulent undercurrents, undercurrents into which the reader is plunged.

This article has two main parts. The first will explore the 'surface', the calm still waters of what we might call artlessness or naivety. The second will dive beneath the surface, and survey some of the undercurrents. This is not intended to be a rehearsal of the literary artistry and sophistication that has been observed in the book, though there will be some overlap. For some critics, such artistry could itself be artlessness; for others, artlessness is artistry. Beauty is in the eye of the beholder. Precisely how we categorise is not ultimately significant, provided that we recognise that it is often in the very places of apparent artlessness that there are hidden depths, a certain swirling turbulence. This is not an attempt to read against the grain. The very artistry and structure implies an intentionality that demands first a sympathetic hearing. It may be, of course, that these observations go beyond authorial intention, though given the artistry and structuring, it would be hard to deny to the author an intentionality here.

\section{The Surface}

In Clines's brief exploration of the prologue of Job, he notes four features that might point toward a certain artlessness or naivety: the language has in his words a 'striking severity' marked by a lack of metaphor; the style is 'plain' with few adjectives; the plot is straightforward; and the structure with scenes alternating beneath earth and heaven is 'its most noticeably naive feature'. In Jonah, working chiefly with Clines's categories, but with some expansion within them, there are very similar elements that give an impression of artless simplicity.

imaginatively engaging narrative that envisages extreme scenarios'. So too Katharine J. Dell, 'Reinventing the Wheel: The Shaping of the Book of Jonah' in After the Exile: Essays in Honour of Rex Mason, ed. John Barton and David J. Reimer (Macon, GA: Mercer University Press, 1996): 97.

9 Clines, 'False Naivety', 735. 


\subsection{Style}

\subsubsection{Adjectives}

There are few adjectives in Jonah. By far the most common is לוֹד great. It occurs fourteen times in the book, in thirteen of the forty-eight verses. ${ }^{10}$ Nineveh is the 'great city' $(1: 2 ; 3: 2-3 ; 4: 11)$, designated as such by YHWH in his first and last words in the book; YHWH hurls a 'great wind' (1:4), bringing on a 'great storm' $(1: 4,12)$; the sailors fear with a 'great fear' $(1: 10,15)$; YHWH appoints a 'great fish' $(2: 1$ [ET $1: 17])$; those in Nineveh who fasted and put on sackcloth were 'from the greatest' to the least (3:5); it was the king 'and his great ones' who issued the decree calling for fasting and repentance (3:7); Jonah was displeased with a 'great' displeasure at YHWH's relenting from the judgement he was to bring (4:1); but later Jonah had 'great joy' over the plant that YHWH had provided for him to shield his head from the sun (4:6). The only other adjectives that occur are the antonym of

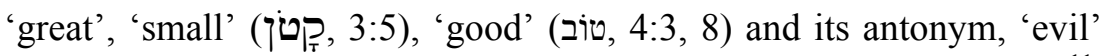

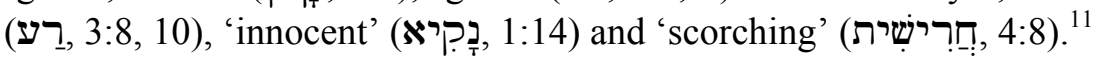

\subsubsection{Literary characteristics}

A number of literary characteristics reinforce the straightforward simplicity. Some are common to Hebrew narrative although particularly marked in Jonah.

Almost all of the main clauses in the narrative of Jonah have a wayyiqtol verb form as the predicate. ${ }^{12}$ There is only one disjunctive circumstantial clause providing background information in the whole book (Jon. 3:3). The opening chapter of Ruth, in contrast, has eight such clauses. ${ }^{13}$ The effect of the preponderance of wayyiqtol forms is to

10 In English versions, 'great' appears $6 \times$ in NRSV; $8 \times$ in ESV; $9 \times$ in NIV (1984); $12 \times$ in NASB.

11 The participle יריז , functioning as a verbal adjective, occurs in 1:9 (cf. JM §1211). Note that John A. Cook, 'The Hebrew Participle and Stative in Typological Perspective', JNSL 34 (2008): 1-19 argues that the Hebrew participle should be classified as an adjective. The phrase rendered 'holy temple' in English versions in 2:4,

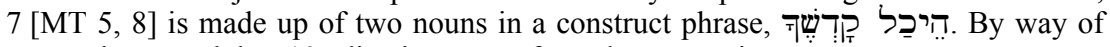
comparison, Ruth has 10 adjectives apart from demonstratives.

12 On my count, there are 80, although two of them in Jon. 1:5 continue the anterior

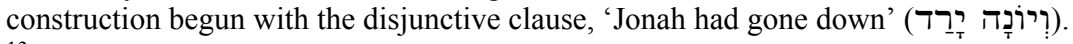

13 The other three disjunctive clauses occur in 1:4-5. Two carry forward the main line of events, and probably have the subject before the qatal verb form for topicalisation.

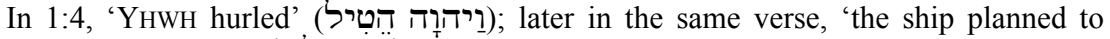

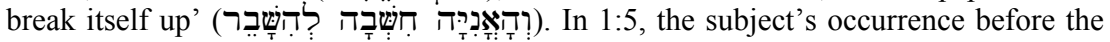


give a sense of narrative momentum, carrying forward the storyline in unbroken fashion, focusing economically on events rather than on broader development through scene-setting or circumstantial information.

A number of words are repeated extensively, beyond לạT: (דע(ז/ע, 'evil, wickedness, distress' (see further below); whether of proclaiming a message or calling out in prayer, which occurs nine times (including the noun 'proclamation' in 3:2); (ה), יריָ 'fear', which occurs six times in chapter 1; שוּב, 'repent, turn', which occurs four times in 3:8-10 and acts as a theme word in chapter 3 as does in chapter 1 .

Repetition of phrases, as well as words, is common. Some occur twice, such as 'for the sea grew more and more tempestuous' $(1: 11,13)$ or 'it is better for me to die than to live' $(4: 3,8)$. Others occur three

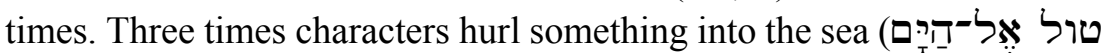
...): YHWH hurls a great wind, the sailors hurl the ship's containers, finally the sailors hurl Jonah $(1: 4,5,15)$; in 1:7, the root פָּפָ ('cast',

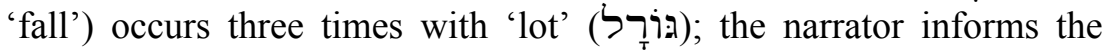
reader three times that Jonah was fleeing 'from the presence of YHWH'

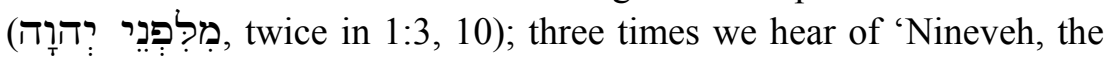
great city' (1:2; 3:2; 4:11); three times the sailors 'fear' (יריר 1 , 1:5, 10, 16).

Beyond repetition of words, there is the common motif of 'anger' expressed by different words: in 1:15, the sea ceases from 'its raging'

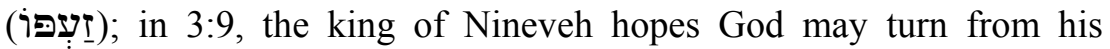

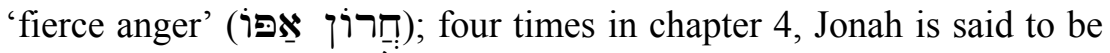
angry $(4: 1,4,9 a, 9 b)($ ) $(?)$ ? $)$. He is angry not just at the moment when, but precisely because, God, who Jonah knows is 'slow to anger'

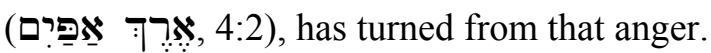

Other elements of the narrative are expressed in such a way as to foster a folk-tale dimension. YHWH 'assigns' a fish, a plant, a worm or an east wind as if allocating resources (2:1 [ET 1:17]; 4:6, 7, 8). ${ }^{14}$ YHWH speaks to the fish, which dutifully vomits Jonah onto the dry ground (2:11 [ET 2:10]).

qatal predicate indicates temporal anteriority (or, perhaps, contrast): 'Jonah had gone

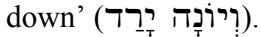

14 The piel of מנד has that sense of allocate or assign in Job 7:3 and Daniel 1:5, 1011 . 
There is the personification of the boat, for Jonah does not pay 'his fare' but gives 'its (the boat's) wage' (שָָָׁרָדָיה 1:3) possibly chartering the vessel as a whole. ${ }^{15}$ Later, as the wind and waves buffet the boat, it 'plans (חשב , piel) to break itself up' (1:5). When the sailors have thrown Jonah into the sea, the sea stands still from 'its raging' (1:15).

There is also paronomasia, playing on the sounds of different words. Divine agents are not just 'assigned' but also characterised by word

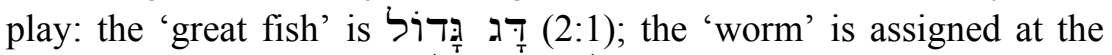

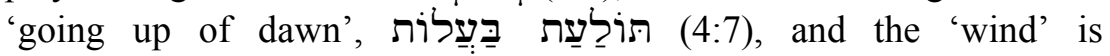

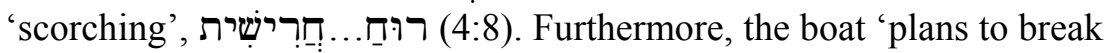

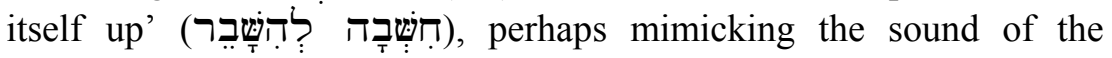
contorted wooden planks (1:4); the 'decree' (טֵַַע) of the king of Nineveh is that neither human nor animal should 'taste' (טעם anything (3:7); in that same decree, the Ninevites, characterised by

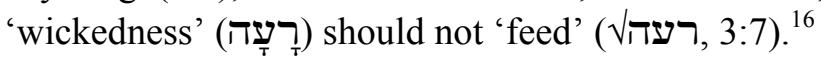

\subsection{Plot}

\subsubsection{Extreme Scenarios}

Clines illustrates the apparent naivety of the plot in the prologue of Job with some of the descriptions of Job. He is described as the 'greatest' (Job 1:3); there is 'none like him on all the earth' (Job 1:8); and he is afflicted 'from the sole of his foot to the crown of his head' (Job 2:7). ${ }^{17}$

That same sense of the ultimate, or extreme scenarios, is apparent everywhere in the book of Jonah, and not just in the recurrence of the word 'great'. There is Nineveh itself, whose size is highlighted in the only scene-setting non-wayyiqtol clause in Jonah, rendered by the NRSV, 'Now Nineveh was an exceedingly large city, a three days' walk across. ${ }^{18}$

15 See further Jack M. Sasson, Jonah: A New Translation with Introduction, Commentary, and Interpretation (AB, vol. 24b; New York: Doubleday, 1990): 83-84.

16 See further Baruch Halpern and Richard E. Friedman, 'Composition and Paronomasia in the Book of Jonah', HAR 4 (1980): 79-92.

17 The 'plot' is more broadly to do with ordering and arrangement of the events. See Jean Louis Ska, 'Our Fathers Have Told Us': Introduction to the Analysis of Hebrew Narratives (Subsidia Biblica 13; Rome: Pontifical Biblical Institute, 1990): 17.

18 We shall return to the first part of the description below. The second part is better rendered as a figure of speech, 'three day walk' (Charles Halton, 'How Big Was Nineveh? Literal Versus Figurative Interpretation of City Size', BBR 18, no. 2 [2008]: 207). Halton (p. 205) insists that this is different from an exaggeration. 
There are extravagant actions or reactions. When the word of YHWH comes to Jonah, he flees as far as possible in the wrong direction. Jonah responds to being swallowed with an effusive song of thanksgiving and deliverance, while many might expect a somewhat different reaction to being devoured whole. In chapter 4 , he reacts with the greatest indignation then a dramatic death-wish to YHWH's relenting (4:1). A few narratival moments later, he feels profound joy at the provision of a shady plant (4:6), only to express that same dramatic death-wish when a God-appointed worm destroys the plant.

The sailors respond to the stilling of the storm with breathtaking devotion to YHWH, fearing YHWH in a way that contrasts with Jonah (1:16; cf. 1:9), offering sacrifices and vows. The Ninevites hear the shortest of prophetic messages and every one of them responds, from 'the least to the greatest', proclaiming a fast and putting on sackcloth (3:5); there needed no decree from the king to enforce it, for it had already happened. Their response far outstripped the reaction of Israel to any prophetic utterance. Nonetheless, as if not to be outdone, the king humbles himself and issues a decree that surpasses their fast, bringing animals into its purview. Again, his response surpassed that of any king in Israel. ${ }^{19}$

Alexander has argued that this sense of exaggeration should not be overstated. The incidents would need to be 'great' to elicit 'great' responses. Furthermore, accounts are told in somewhat understated fashion, such as YHWH's 'assigning' a fish, a plant, a worm or an east wind $\left(2: 1\right.$ [ET 1:17]; 4:6, 7, 8). ${ }^{20}$ However, such a reading fails to account for the stereotypical nature of the repetition of לiדis. In addition, the actions that the assigned agents perform and the way that they perform them are anything but ordinary. The fish swallows Jonah and spits him out onto the dry ground at YHWH's behest (2:1 [ET 1:17], 10). The plant sprouts up to order, with a design to shade Jonah's head; later we discover, it grew very quickly $(4: 6,10)$. The worm does not simply 'eat' or 'devour', but 'strikes' or 'attacks' the plant ( נכהז, 4:7; cf. Deut. 28:39). ${ }^{21}$

19 The closest is David's response to Nathan. See esp. 2 Sam. 12:16-17, 20, 22.

20 Cf. T. Desmond Alexander, 'Jonah and Genre', TynBul 36 (1985): 48-49.

21 Yvonne Sherwood, A Biblical Text and Its Afterlives: The Survival of Jonah in Western Culture (Cambridge: Cambridge University Press, 2000): 241. 


\subsubsection{Binary View of the World}

A sense of simplicity is also apparent from the binary view of the world ${ }^{22}$ that the book presents. The construction of space reflects this. Up represents where YHWH is, down represents movement away from YHWH, ultimately to the realm of death and Sheol (cf. 1 Sam. 2:6; Job 7:9). The Ninevites' רָזָד has 'gone up' (עָד (עדָ) before me, says YHWH (1:2); Jonah is to 'get up' (קרום 'P, 1:2) as the first step of fulfilling his commission. But Jonah's journey is in the opposite direction. He goes down (ירָד (רָרד) to Joppa. His descent continues, as he goes down into the boat (ירָד $, 1: 3 \mathrm{~b})$. But that is far from the end of his downward journey. The sailors frantically hurl containers into the sea, but Jonah 'had gone down' (ירָד , 1:5) into the depths of the vessel; the verb that speaks of

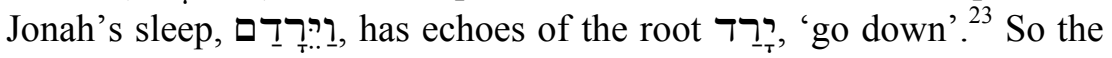
captain summons him to 'get up' ( $\square$ ip, 1:6) and pray. That descent continues further when the sailors hurl Jonah into the sea. As he looks back from the comparative safety of the fish's stomach, he recalls how he 'went down' (ירָד , 2:7 [ET 6]) to the earth. He was submerged as all YHWH's breakers and waves passed over him (2:4 [ET 3]). But even in the belly of the fish, his upward journey had started, for Jonah recalls how YHWH had 'brought up' (עָ עָ 2:7 [ET 6]) his life from the pit. The recommissioning of Jonah begins as YHWH tells Jonah a second time to 'get up' (קוּ, 3:2). The king of Nineveh's first response to Jonah's preaching is to 'get up' (קוֹ $\mathbf{\square}, 3: 6)$ from his throne.

Alongside that vertical construal of space, there is also the horizontal. Jonah is to 'get up and go to Nineveh'. Nineveh is the place of obedience. Jonah does not just 'go down' but he also flees away, to Tarshish. Tarshish symbolically represents not just the opposite direction, but in all probability the furthest known point in that direction. Such a flight is said to be 'from the presence of YHWH' (1:3 $(\times 2), 10$; cf. Gen. 4:16; Ps. 51:13 [ET 11]). ${ }^{24}$

22 To borrow words from Newsom, Book of Job, 45. She in turn is picking up from Susan Rubin Suleiman.

23 J. A. Ackerman, 'Satire and Symbolism in the Song of Jonah' in Tradition in Transformation: Turning Points in Biblical Faith: To Frank Moore Cross on the Occasion of His 60th Birthday July 13, ed. Baruch Halpern and Jon. D. Levenson (Winona Lake, IN: Eisenbrauns, 1981): 223.

24 For more on space, see Albert Kamp, Inner Worlds: A Cognitive Linguistic Approach to the Book of Jonah (Biblical Interpretation Series 68; Boston, MA: Brill, 2004): 116-24. 
A third binary conception is that of 'life and death'. What is at stake throughout the book is 'life' and 'death'. The sailors' concern is that they will 'perish' in the storm (אָָ אבד 1:6). Later, they are afraid that by hurling Jonah into the sea and thus taking away his life (נְֶֶֶ, 1:14)

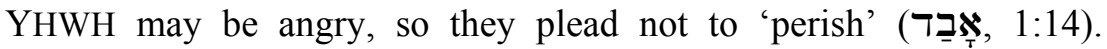
Throughout the song of thanksgiving in chapter 2, matters of life and death are central. In the sea, Jonah had been 'in the belly of Sheol'; ${ }^{25}$ the waters had almost swamped him (נְֶֶפ, 2:6 [ET 5]); but YHWH

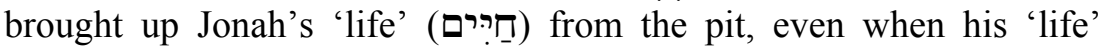

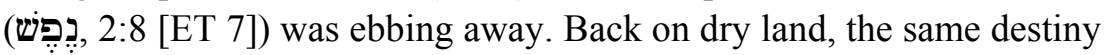
that confronted the sailors, of 'perishing' (אָבָד), is one that the Ninevite king and his 'great ones' are likewise desperate to avoid (3:9).

In chapter 4, livid with YHWH's relenting from judgement, Jonah declares that 'dying' (מות) is preferable to living (4:3). Later, as he is fainting in the heat after the plant that brought him great joy has 'perished' (אָבָד 4:10), he again repeats his request, the narrator highlighting with the introduction, 'he asked to die' (מוּת, 4:8). When YHWH in turn repeats his question about the appropriateness of Jonah's anger, Jonah insists this time that he is 'angry enough to die

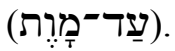

The polarity of 'life and death' is matched by that of 'good and evil'. A root that recurs throughout the book is (ע) (ע), whether as a

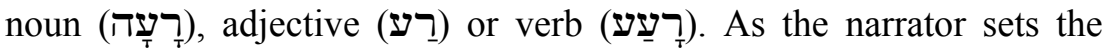
scene for the whole book, YHWH declares of Nineveh that 'theirpresumably, its inhabitants'-wickedness' (굮) has gone up before him. The result of Jonah's flight is that YHWH sends a storm in judgement, a storm that the sailors identify as an 'evil' (רָָָָָ, in the sense of calamity; 1:7-8). When Jonah eventually goes to Nineveh, the king's decree insists that human being and animal alike should turn from their 'evil' way (ער $, 3: 8)$. When God sees that they have indeed turned from their 'evil' way (ער $2,3: 10)$, he in turn relents from the 'evil' (רָָָָ , in the sense of calamity; 3:10) that he would have inflicted. This whole turn of events is then extremely 'evil' to Jonah

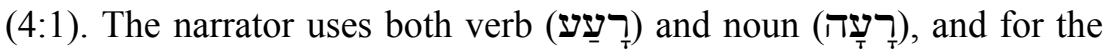

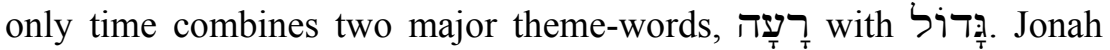
explains why he is so aggrieved, for he had known even at the

25 Though one might understandably have thought that the stomach of the fish was akin to the 'belly of Sheol'. 
commissioning that YHWH is a God who relents of 'evil' (רָָָָ , 4:2). Because YHWH had relented, Jonah insists that for him death is 'better' (טוב, 4:3) than life. YHWH questions him, 'Is it good (רָטֵ) for you to be angry?' (4:4). Later, after the plant has perished, Jonah again asserts that for him death is 'better' (טוב (ר), 4:8) than life, and God

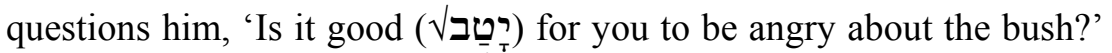
Jonah insists that it is 'good' (ריטֵבר) for him to be angry (4:9).

\subsection{Structure}

Ben Zvi comments that Jonah is 'atypical' when compared with the 'multiple possible outlines' that characterise other prophetic books: 'the book of Jonah shows a relatively tight structure'. ${ }^{26}$

The strongest parallels occur in chapters 1 and 3 . The opening verse of each chapter is identical, except that in 3:1 'a second time' replaces 'son of Amittai' in 1:1: 'the word of YHWH came to Jonah son of Amittai, saying'; after the word-event formula, YHWH's word to Jonah is given. Both commissions begin with 'Get up, go to Nineveh, the great city and proclaim'. In response to the injunction, both record 'Jonah got up', though in chapter 1 it was 'to flee to Tarshish from the presence of YHWH' while in chapter 3 the structural correspondence belies an opposite course, "to go to Nineveh according to the word of YHWH'. In both chapters, Jonah then encounters a group of heathen on his travels.

Both groups of heathen are characterised by striking piety and devotion, especially in response to the words that Jonah utters. The sailors cry out (זעק 1:5) to their deities as well as hurling their cargo into the sea; later they call to YHWH (קרא, 1:14). The Ninevites call ( then falls on a heathen leader who is marked by even more striking piety. The captain of the boat unwittingly echoes YHWH's commission when he summons Jonah, the pious Israelite, to 'get up' from his sleep and 'call' (קום ... 1:6; cf. v. 2) on his God, wondering whether 'God' will spare him a thought. The king of Nineveh gets up (קום) from his throne; he issues a proclamation (זעק, 3:7) and, like the captain, urges others — his people — to call (קרא) on God (3:8); he too

26 Ehud Ben Zvi, Signs of Jonah: Reading and Rereading in Ancient Yehud (JSOTSup, vol. 367; London: Sheffield Academic Press, 2003): 27. See further Trible, Rhetorical Criticism, 110-17. 
wonders whether God will relent (3:9). ${ }^{27}$ The captain and the king are both keen 'that we will not perish' (ולא נזברד, 1:6; 3:9). Sailors and Ninevites alike are faced with the רָָָדָ (1:7-8; 3:10). In Exodus 14:31, the Israelites, having seen YHWH's great power in the exodus, 'feared YHWH' (ירא את יהוה) and

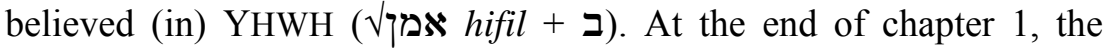
sailors 'feared YHWH' greatly (ירא את יהוד), 1:16); after Jonah's proclamation in chapter 3, the Ninevites 'believed God' (את ירתן hifil + ב, 3:5). ${ }^{28}$ After the sailors' action of hurling Jonah into the sea, the sea ceases from its raging, perhaps a metonymy for YHWH's own raging (1:15); after the Ninevites' repentance, God relented from his anger (3:9-10).

There are also parallels between chapters 2 and 4. At the structural level, both begin with Jonah 'praying' (פלל פל hitpael) to YHWH (2:2 [ET 1]; 4:2) followed by a report of his prayer, begun with wayyiqtol of אמר. Both prayers start with a backward glance to a narrative moment that the reader only encounters in retrospect through Jonah's words to YHWH. In both, Jonah quotes or follows closely words found elsewhere in the Old Testament. YHWH responds to Jonah's prayer by speaking and by assigning an agent from nature to act in relation to Jonah. At the thematic level, both chapters focus on the relationship between YHWH and Jonah; other involvement is restricted to divinely assigned agents (fish, plant, worm and wind). Both, as Jenson observes, 'provide pause for reflection following eventful narration' and chapter 4 'continues and builds upon the basic theme of ch. 2, the mercy of YHWH who saves those who cry to him'. ${ }^{29}$

Alongside broader structural parallels within Jonah, there are also more local correspondences. The sailors' ever more frantic action in the face of the storm and the ship's imminent destruction is matched by the lengthening of the three clauses that describe it (1:5a); in contrast, Jonah's descent to sleep is similarly expressed by three clauses, but

27 Given other parallels between Jonah and Jeremiah 36 or Joel 2, it is striking that the sailors speak of the 'perhaps' (אוּליר) of Jeremiah 36:3, 7, and the king of Nineveh speaks of the 'who knows' (מי יריוֹעַ) of Joel 2:14. See Rob Barrett, 'Meaning More Than They Say: The Conflict Between YHWH and Jonah', JSOT 37 (2012): 255.

28 For the sense that the Ninevites 'believed' God rather than 'believed in' God, see especially John H. Walton, 'The Object Lesson of Jonah 4:5-7 and the Purpose of the Book of Jonah', BBR 2 (1992): 47-57.

29 Philip P. Jenson, Obadiah, Jonah, Micah: A Theological Commentary (LHBOTS, vol. 496; New York: T\&T Clark, 2008): 58. 
Jonah's move to inactivity is matched by the short clauses whose only

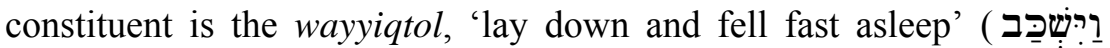
 words, the same as God's speech at the end of the chapter; similarly, both have thirty words when maqqephs are regarded as bracketing words together. ${ }^{30}$

\section{Undercurrents}

On the surface, style, plot and structure all indicate a certain artless simplicity or, in Clines's word, naivety. Beneath the surface, though, are hidden depths. Many scholars have highlighted the irony that is ubiquitous in Jonah. Irony is rooted in contrast, immediately evident to reader or character or both. It may be verbal, the contrast between what is said and what is meant, or dramatic, the contrast between what a character knows, on the one hand, and what the author and reader know, on the other. ${ }^{31}$ In Jonah, for example, there is verbal irony where he declares that he 'fears' YHWH, which could mean that he reveres YHWH, but could also mean that he is afraid of YHWH (1:9). ${ }^{32}$ There is dramatic irony, seen in the contrast of what might be expected from a prophet and a pagan and what is actually seen. ${ }^{33}$ Perhaps the greatest irony of all is that Jonah has the profoundest of insights, that the character of YHWH as gracious and compassionate - a character trait from which he has personally benefited (7סֶ, $2: 9$ [ET 8]; 4:2) —has a bearing on the Ninevites, yet at that very moment he resents it $(4: 2)$.

30 Trevor Dennis, 'God's Fool II: This Time in Berlin' in Lo and Behold!: The Power of Old Testament Story Telling, reprint, 1991 (London: SPCK, 2010): 134; cf. Sasson, Jonah, 317.

31 Cf. Ska, 'Our Fathers Have Told Us', 57-61.

32 Ska, 'Our Fathers Have Told Us', 59-60.

33 See especially Edwin M. Good, Irony in the Old Testament (Philadelphia: Westminster, 1965). Some have pushed this further, towards satire or parody, e.g., John A. Miles, Jr., 'Laughing at the Bible: Jonah as Parody', JQR 65, no. 3 (1975): 168-81; John C. Holbert, “'Deliverance Belongs to Yahweh!": Satire in the Book of Jonah', JSOT 21 (1981): 59-81; Ackerman, 'Satire and Symbolism'; David Marcus, From Balaam to Jonah: Anti-Prophetic Satire in the Hebrew Bible (BJS, vol. 301; Atlanta, GA: Scholars Press, 1995). Note the recent cautions of Jenson, Obadiah, Jonah, Micah, 33-34; Uriel Simon, Jonah: The Traditional Hebrew Text with the New JPS Translation (JPS Bible Commentary; Philadelphia: Jewish Publication Society, 1999; tr. Lenn J. Schramm): xxi-xxii; Will Kynes, 'Beat Your Parodies Into Swords, and Your Parodied Books Into Spears: A New Paradigm for Parody in the Hebrew Bible', Biblical Interpretation 19, no. 3 (2011): 276-310. 
Rather than rehearse the irony that may be found, I want to observe that it is often in precisely the places where an artless simplicity may be discerned that there are hidden depths.

\subsection{Style}

\subsubsection{Adjectives}

The recurrence of לדוֹד , 'great', particularly when set against the relative lack of other adjectives, at first appears artless. After all, most parents tell their children when they are writing a story not to use 'big' the whole time. But sometimes its use is not quite as straightforward. In what sense is Nineveh 'great'? In 3:3, the narrator describes Nineveh,

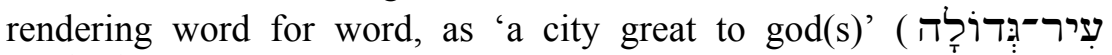
(לאלדהים (ל) Some have seen the phrase as an elative, another way of expressing the extraordinary size of the city rather than its having any significant theological import. This is reflected in English Bibles from the King James Version ('an exceeding great city') through to the 2011 New International Version ('a very large city').

But a number of factors coalesce to suggest something more theologically significant. First, syntactically, this is not the characteristic way of expressing an elative. Normally the noun is in construct with אֶים or or

Second, of the four instances of Nineveh's being described as 'great' in Jonah, this is the only one explicitly from the narrator's pen. All the other three are on the lips of YHWH (1:2; 3:2; 4:11). YHWH speaks five times in the book. Two are terse questions asking whether Jonah is rightly angry $(4: 4,9)$. In each of the others, YHWH designates Nineveh as 'great'. If Nineveh is great, it is great in the eyes of YHWH. ${ }^{35}$

Thirdly, on one occasion the cognate verb לָד a appears. In 4:10-11, YHWH contrasts Jonah's pity over a plant with his own over Nineveh. Jonah has pity on a plant over which he had not 'laboured' and which he had not 'made great' (גדלר). YHWH continues by talking of pity for Nineveh, the 'great city'; presumably YHWH is the one who has 'laboured' over Nineveh and has made it great.

\footnotetext{
$34 \mathrm{JM} \S 141 \mathrm{n}$.

35 This, incidentally, makes it implausible to think of לאלדהים as 'to gods' and the whole phrase as 'great to gods'.
} 
Thus at first glance 'great' seems to be a somewhat straightforward description of the city's size. But beneath the surface is the city's significance to $\mathrm{YHWH}$, all the more shocking given its violence and its role in Israel's history. ${ }^{36}$

\subsubsection{Literary Characteristics}

The repetitions that occur in Jonah sometimes have subtle shifts associated with them. It has often been noted how the sailors in chapter 1 move from fearing (יראז, v. 5) to fearing greatly (יראאיר,, v. 10) to fearing YHWH greatly (יראירו, v. 15). That acquires a greater piquancy when set against Jonah's statement that 'it is YHWH, the God of heaven, that I fear (יראו , v. 9)'. The literary artistry of the 'growing phrase' may be noted. ${ }^{37}$ But there is more. In and through the confession of Jonah, with YHWH fronted for effect, and his (presumed) death, the well-meaning and devout, but ultimately pagan, sailors become YHWH-fearers. Questions about whether the sacrifice was on board, or promised, presumably in Jerusalem (so the Targum), should not hide the immensity of the statement.

Wordplays, too, are not always merely aesthetic. In 4:6, YHWH God

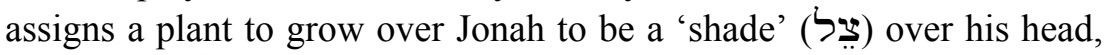

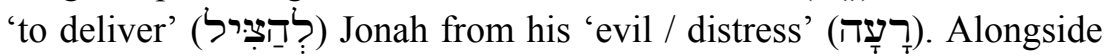
the 'narrator's pleasure in the alliteration', ${ }^{38}$ there is something much deeper going on. One possibility is that the phrase means 'to shade Jonah from his discomfort'. The LXX reads it that way, rendering the

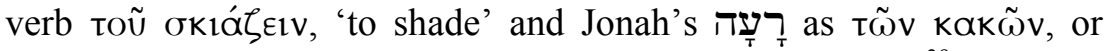
'woes', the only time רָָָד is rendered this way in Jonah. ${ }^{39}$ With the Masoretic Text as it stands, the verb must be 'to deliver'. ${ }^{40}$ But because of the potential ambiguity of

\footnotetext{
36 See further Sasson, Jonah, 228-30. He translates 'literally' because he cannot 'pin down' the phrase's meaning.

37 See, e.g., Jonathan Magonet, Form and Meaning: Studies in Literary Techniques in the Book of Jonah (2nd edn, Bible and Literature Series, vol. 8; Sheffield: Almond, 1983): 31-32.

38 Hans W. Wolff, Obadiah \& Jonah (Hermeneia; Minneapolis: Augsburg, 1986; tr. Margaret Kohl): 171. Note the corresponding 'shaded-saved' of Gerda Elata-Alster and Rachel Salmon, 'The Deconstruction of Genre in the Book of Jonah: Towards a Theological Discourse', Journal of Literature and Theology 3, no. 1 (1989): 55, something that Jonah refuses.

39 Perhaps indicating that it is reading the hifil infinitive construct of III לדצל ,צלל.

40 It is the hifil infinitive construct of נצל
} 
either 'to deliver Jonah from his distress' ${ }^{41}$ or, more pungently, 'to deliver Jonah from his wickedness'. Is YHWH going to deliver Jonah from his distress due to the heat on his head? Or because of the distress that he felt in 4:1-3 over the sparing of Nineveh? Or because of his evil, because he has been angry without justification? And if he is going to do so, how does the plant help? At one level, it provides shade. But at another level, might it provide an object lesson? Given that the plant thrives for a time ('became great') and then perished at God's hand, perhaps, after all, Yahweh is going to bring destruction on the great city of Nineveh?

A third literary characteristic observed earlier is the marked preference for wayyiqtol forms to carry the narrative forward with a succession of events that follow naturally and sometimes breathlessly after each other. But that is not always the case. In 1:3, after YHWH's

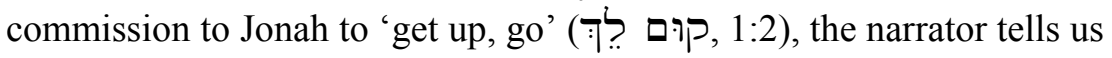

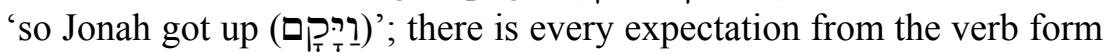
that dutiful obedience will follow. Instead of the expected 'and he went to Nineveh' (cf. Num. 20:20-21; 1 Kgs 17:9-10), however, the syntactical continuity conceals a semantic discontinuity. As Trible puts it, 'the ambiguity of $w a-$ leads and misleads'. ${ }^{42}$ She translates by 'but'. A translation that captures the force better might be, 'So Jonah got up [barely perceptible pause] to flee to Tarshish.'

In 4:5, another wayyiqtol form is the scene of significant scholarly discomfort. Following directly from YHWH's questioning of Jonah, the narrator records (NRSV) 'Then Jonah went out (ורי: (1) of the city and sat down east of the city, and made a booth for himself there. He sat under it in the shade, waiting to see what would become of the city.' Two particular puzzles arise for the interpreter here. First, Jonah has made a booth that provided shade for him, yet in verse $6 \mathrm{YHWH}$ assigns a plant to 'shade' Jonah. Secondly, Jonah has already seen what has happened to the city, and it greatly displeased him. Some suggest verse 5 should be relocated to a putative original position after $3: 4 .{ }^{43} \mathrm{It}$

41 Cf. Ps. 34:20 [ET 19]; Exod. 5:23, where the hifil of the root נצ' delivering God's people from their ill-treatment (רעע) at the hand of Pharaoh.

42 Phyllis Trible, God and the Rhetoric of Sexuality (Philadelphia: Fortress, 1978): 128.

43 E.g., John Day, 'Problems in the Interpretation of the Book of Jonah' in In Quest of the Past: Studies on Israelite Religion, Literature and Prophetism, ed. A. S. van der Woude (Oudtestamentische Studiën, vol. 26; Leiden: Brill, 1990): 42-43. 
fits with the clustering of the word 'city' in $3: 2-4^{44}$ as well as smoothing out awkwardness over events in the city. However, it does not entirely remove the problem of the need for shade in $4: 6,{ }^{45}$ nor is a good reason for its new position in chapter 4 obvious. Furthermore, it is unlikely that Jonah as subject would appear twice, 'Jonah began to go into the city ... and he proclaimed and he said ... and Jonah went out' (3:4). We would expect 'he went out' ${ }^{46}$ It is also unlikely that God would act in 4:6 without any indication of a response to his question of $4: 4$, 'Are you right to be angry?'

A second explanation, popular since an article by Lohfink in 1961, although with an older pedigree, is to see the verb form here as indicative of a flashback, 'now Jonah had gone out', in its present position to facilitate the flow of the narrative. ${ }^{47}$ It is true that there are instances of what Zevit terms 'scrambled sequences', wayyiqtol verb forms which clearly do not follow temporally from each other, but where the second event must precede the first (e.g. Exod. 4:31). ${ }^{48}$ But these tend to be transparently the case, and this is not so here. ${ }^{49}$

The third explanation is to read it in sequence. Jonah responds to YHWH's question not with words but with an action, somewhat similar to the flight in $1: 3{ }^{50}$ Behind the simple wayyiqtol form there is an undercurrent. If read in sequence, as is plausible to me, suddenly a new world of interpretation is introduced. Was Jonah hoping to persuade YHWH to change his mind one more time, influenced by his own courageous stand? Is the preservation of Nineveh suddenly in

\footnotetext{
44 Trible, Rhetorical Criticism, 205.

45 Unless it is assumed that his booth ceased to be effective by the end of the 40 days' grace of his proclamation, or, as a colleague who worked for a number of years in the Central African Republic observed, a plant's shade is always preferable to a building's. 46 This pattern of keeping the discourse-active topic covert obtains throughout Jonah, except for repetition of 'God' in 3:10.

47 Norbert Lohfink, 'Jona ging zur Stadt hinaus (Jona 4,5)!', Biblische Zeitschrift 5 (1961): 185-203. The Jewish exegete Ibn Ezra had already proposed this.

48 Ziony Zevit, The Anterior Construction in Classical Hebrew (SBLMS 50; Atlanta, GA: Scholars Press, 1998): 69-71.

49 Elata-Alster and Salmon ('Deconstruction of Jonah', 50) regard this as the most likely historical ordering, and see the verb form as contributing to their deconstructionist reading: 'the normative genre is given to the reader and withheld from him at once'.

50 So, e.g., Magonet, Form and Meaning: Studies in Literary Techniques in the Book of Jonah, 58, 60; James Limburg, Jonah: A Commentary (OTL; Louisville, KY: Westminster John Knox Press, 1993): 94 n. 166.
} 
jeopardy? And how long is Jonah prepared to wait? A booth suggests that he is in it for the long haul.

\subsection{Plot}

\subsubsection{The Initial Commission}

The plot of a narrative is, as Bar-Efrat puts it, 'a meaningful chain of interconnected events' arranged to 'arouse the reader's interest and emotional involvement'. ${ }^{51}$ Readers often note the striking delay between Jonah's commission and flight in 1:2-3 and his explanation for that flight in $4: 2$. For a first-time reader of Jonah, there is a different experience from one familiar with the book. Usually attention is focused on Jonah's reason for fleeing, but there is more.

Jonah is to go to Nineveh, and utter a proclamation (קרא). But in the rest of $1: 2$, there is scope for ambiguity. Some has been noticed, not

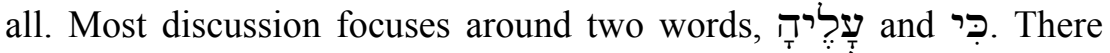

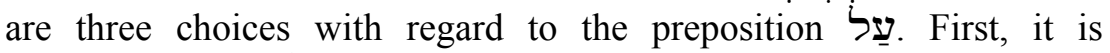
synonymous with אֶ, meaning 'to'. That sense of 'preaching to' (with (א) is found in the parallel passage in 3:2, and is based on a degree of interchangeability between the prepositions found in later Hebrew. ${ }^{52}$ The second is that it means 'against', as found, for example, in the man of God denouncing the altar in 1 Kings 13:2. Sasson insists that this is the only possible rendering of קרא עַל, as opposed to treating the preposition in isolation..$^{53}$ However, there is a third possibility, עַ עַ as 'concerning', found in Nehemiah 6:7. There, Sanballat's unsealed letter accuses Nehemiah, amongst other things, of appointing prophets 'to proclaim (קרא) in Jerusalem concerning (עַל) you'.

The second is the particle כִי. This could be causal, as most English translations take it, giving the grounds for the proclamation, 'for'; it could be asseverative, "surely'; ${ }^{54}$ a third possibility is that it is a

51 Shimon Bar-Efrat, Narrative Art in the Bible (JSOTSup 70, Bible and Literature Series 17; Sheffield: Sheffield Academic Press, 2000; tr. Dorothea Shefer-Vanson): 93.

52 For other reasons, see Ben Zvi, Signs of Jonah, 36-37.

53 Sasson, Jonah, 72-75.

54 The 'emphatic' or 'asseverative' use of כִּ has been defended by Anton Schoors, 'The Particle 'כי' in Remembering All the Way...: A Collection of Old Testament Studies Published on the Occasion of the Fortieth Anniversary of the Oudtestamentische Werkgezelschap in Nederland, ed. Bertil Albrektson (Oudtestamentische Studiën, vol. 21; Leiden: Brill, 1981): 240-76. The subsequent work on Dִ כִ by Anneli Aejmelaeus ('Function and Interpretation of כי in Biblical Hebrew', JBL 105 [1986]: 193-209) narrowed down the occurrence of the asseverative 
complementizer, 'that', introducing the contents of the proclamation as a noun clause. ${ }^{55}$ Although commentators and English Bibles tend to go with 'for' here, intriguingly the same collocation of בִּי קרא in Isaiah 40:2 tends to be translated, 'Speak tenderly to Jerusalem, and cry to her that she has served her term' (so NRSV). What is at issue here is whether the clause introduces the grounds for the proclamation or its content.

A third potentially ambiguous word is assume that the sense 'their wickedness' is obvious. That is certainly the most common meaning of רעה in Jonah and elsewhere. However, later in Jonah, it can have the meaning of 'affliction' (cf. NRSV 'discomfort', 4:6). There is not necessarily a moral judgement in the word at all. In Psalm 34:20 [ET 19], the psalmist declares, 'Many are the afflictions (רעזוֹ) of the righteous, but YHWH delivers them from them all.' There is a certain implausibility about reading it like this, given Nineveh's likely symbolic function in Jonah as a city of notoriety (cf. Nah. 3:1-4; Zeph. 2:13-15). At the start of the book, not only does the reader not know why Jonah fled, he or she wonders about the purpose of the commission, the content of the proclamation, and even the situation in Nineveh.

The reader can follow a number of reconstructions by filling in the gaps. As Jonah gets up to flee, is he callous, not wanting forgiveness for Nineveh? Is Jonah more callous still, not wanting anything good to happen to a city in distress? Or is Jonah fleeing from a deity determined to bring judgement on a wicked city as Sternberg

function, principally to oaths. Recently, Blane Conklin, Oath Formulas in Biblical Hebrew (Linguistic Studies in Ancient West Semitic, vol. 5; Winona Lake, IN: Eisenbrauns, 2011): 46-59 has proposed that even in oaths sִִ should not be seen as asseverative, but as a complementizer.

55 A complementizer is a function word that introduces a clause, allowing it to be regarded as a noun phrase complement. A fourth option, that it is a complementizer used to introduce direct discourse, the so-called פִ recitativum, cannot be correct here

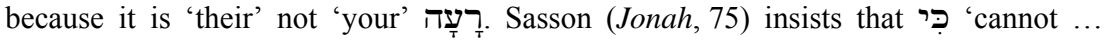
introduce direct speech' and that such a way of translating 'should be deleted from the dictionaries'. His scepticism regarding כִ recitativum matches that of Cynthia L. Miller, The Representation of Speech in Biblical Hebrew Narrative: A Linguistic Analysis (HSM, vol. 55; Atlanta, GA: Scholars Press, 1996): 116; note in contrast $\mathrm{JM} \S 157 \mathrm{c}$ n. 4. However, the translation that Sasson himself gives on that rendering, 'declare against it that its citizens' wickedness' is not a case of יכי introducing direct speech, but as a complementizer introducing oratio obliqua. 
suggests $?^{56}$ For Sternberg, the rest of the opening chapter reinforces that picture, of a God who will apparently stop at nothing so that his prophet will deliver this message of denunciation. 'Innocent' sailors are involved, terrified for their lives. They are driven to cast Jonah into the sea, but not before their precious cargo lies at the bottom of the ocean. In chapter 2, YHWH has pursued the prophet even to the depths, and has brought him back from the grave so he can fulfil his commission. YHWH is relentless in prosecuting judgement on Nineveh, using the prophet Jonah as the effectual emissary. The Ninevites are right to speak of YHWH's 'fierce wrath' (3:9). The reader expects judgement. Then, as Sternberg puts it, a 'series of information thunderbolts shatters the entire model of the narrative world and world view, so that the reader cannot find it easy to get his bearings at once' ${ }^{57}$ Readerly characterisation is turned upside down. YHWH's seemingly vindictive actions are all part of a plan to be merciful; it was Jonah who was vindictive. $^{58}$

\subsubsection{Good and Evil}

The association of (הע) with every character might seem an instance of artless lack of variety. But that association demands comparison of what is meant when it is predicated of the different characters. The initial impetus for the book is Nineveh's רָָָ having gone up before YHWH, later clearly their wickedness (3:8). This same noun is predicated of YHWH's own activity on the lips of the sailors (1:7-8) and the narrator (3:10). In the Old Testament, human רָָָ רָָד tends to elicit YHWH's punitive רָָָ (e.g. Jer. 16:10). The Old Testament unabashedly insists that YHWH stands behind both light and darkness, weal and woe (רָָָ, Isa. 45:7; cf. Job 42:11). In Jonah, that could be the sense of the grievous situation $(\underset{\tau}{T})$ that the sailors or Ninevites find themselves in $(1: 7-8 ; 3: 10)$, whether for Jonah's or their own רָז רư ${ }^{59}$ But at another level, the reader is immediately caused to

56 For this possible construal, see Meir Sternberg, The Poetics of Biblical Narrative: Ideological Literature and the Drama of Reading (Bloomington, IN: Indiana University Press, 1985): 318-20.

57 Sternberg, Poetics, 319.

58 Readers do need to fill in the gaps to consider how YHWH's compassion may be grounds for Jonah's flight, but it is overstating it to say that the link 'remains obscure' (so Barrett, 'Meaning More Than They Say', 239).

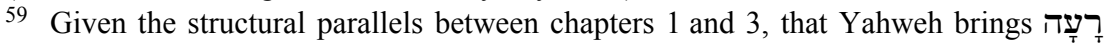

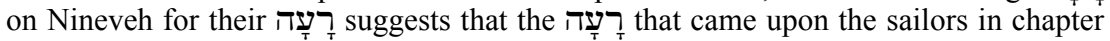
1 is for Jonah's רָזָז, although we are not told. 
compare YHWH's actions with Nineveh's. It is not just that YHWH inflicts something that is experienced as רָָָָ. The question itself comes whether YHWH's own actions themselves are רָָָָָָ ,evil'. The polyvalency of רָָָ means that the moral dimension is not far away. That is reinforced at the end of chapter 3 and the start of chapter 4 . When YHWH relents of the רָָָ that he was going to inflict on Nineveh, Jonah's reaction is framed in the same language:

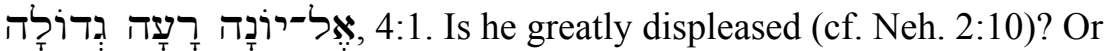
are YHWH's actions 'evil' in Jonah's eyes? The latter suggests YHWH's actions are under scrutiny.

So too are Jonah's. It is in chapter 4 that Jonah's רָָָ comes to the fore. In verse 6, YHWH looks to deliver Jonah from his רָָָָָ Is that compassionate relief for Jonah's discomfort from the sun, patient coaxing from his displeasure at YHWH's relenting, or delivering Jonah from his wickedness? The contrast between Jonah and YHWH could not be more stark. As YHWH relents from his anger and רָָָ , Jonah gets angry and is marked by רָָ רָָ (3:9-10; 4:1,6). Though Jonah is no longer far from where he should be spatially - in Nineveh 'according to the word of YHWH' (3:3), he is in reality far from YHWH.

The same ambiguity is true of what is 'good' (טוב ). The adjective occurs twice in chapter 4. On both occasions, Jonah is insisting that his death is 'better' than his life. The sense seems to be that for Jonah death is preferable to life. YHWH's questioning of Jonah echoes using the related verb יטב. Some commentators see here a question of the depth of Jonah's anger, particularly the adverbial use elsewhere (e.g. Deut. 17:4). ${ }^{60}$ Others think YHWH's question shifts the ground from preference to justification, 'Is it good - in the sense of right-for you to be angry?' especially given the context of verse $9 .{ }^{61}$ Even if the former, it is hard to avoid a punning interplay between preference, 'good', and rightness, 'rightly', of Jonah's anger. Subjective experience and moral value play off against each other.

\subsubsection{Life and Death}

We noted above that there is a certain artlessness in having life and death always at stake within the book of Jonah. However, as with Job,

60 Sasson, Jonah, 286; Simon, Jonah, 38-39.

61 Wolff, Obadiah \& Jonah, 160; cf. Kenneth M. Craig, A Poetics of Jonah: Art in the Service of Ideology (Columbia, SC: University of South Carolina Press, 1993): 178-79; Limburg, Jonah, 94; Jenson, Obadiah, Jonah, Micah, 86. 
life and death do not have the same value for all the characters all the time. $^{62}$

For the sailors, their own death remains something undesirable. They call to their gods; they hurl their precious cargo into the sea; the captain urges Jonah to call on his God 'that we will not perish' (1:6); later, they cry to YHWH, pleading that they 'will not perish' when they hurl Jonah into the sea $(1: 14)$. That sense of death being undesirable extends to the sailors' attitude to Jonah. When Jonah proposes that the sailors hurl him into the sea because he knows that the great tempest is all his fault, their first reaction is to row harder to try and reach the shore. ${ }^{63}$ When their first attempt fails, it is only after a heartfelt prayer that they hurl Jonah over the side. Yet within the narrative flow of the book it is precisely in and through Jonah's 'death', being hurled off the boat and into the depths, that the storm ends. Their response of offering sacrifices and vows anticipates Jonah's thanksgiving for his deliverance (2:10 [ET 9]). For the sailors, the 'death' of Jonah has become the means of their deliverance.

For the king of Nineveh, death is to be avoided. His decree has as its ultimate hope 'that we will not perish' (3:9). Yet his getting up and leaving his throne to sit on ashes is a move towards mourning and death (cf. Isa. 61:3; Job 2:8), a voluntary embracing in the hope of redemption. ${ }^{64}$

For Jonah, his own downward flight intimates if not a death-wish at least a willingness to embrace his own death rather than fulfil his commission. The journey to Sheol or the pit in the Old Testament is a journey down. Jonah's descent in chapter 1 ends in verse 5 with his going down to the 'depths of the vessel' and falling into a deep sleep.

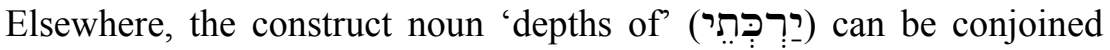
with 'pit' to speak of the depths of the grave (Isa. 14:15; Ezek. 32:23).

\footnotetext{
62 For Job's shifting attitude to death, see especially Rick D. Moore, 'The Integrity of Job', CBQ 45 (1983): 17-31; John E. Hartley, 'From Lament to Oath: A Study of Progression in the Speeches of Job' in The Book of Job, ed. Willem A. M. Beuken (BETL 114; Leuven: Leuven University Press, 1994): 79-100.

63 There is a certain irony, for 'digging' is elsewhere suggestive of a journey down towards death (cf. Amos 9:2).

64 Cf. Jenson, Obadiah, Jonah, Micah, 76.
} 


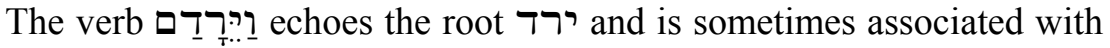
Adam's sleep of death in Genesis 1:21. ${ }^{65}$

Later in chapter 1 when the sailors ask what they should do to Jonah so that the sea should quieten down, Jonah proposes that they pick him up and hurl him into the sea. We are not given a window into Jonah's inner thought life here. That will have to wait until chapter 4 . Wolff regards his request as a straightforward death-wish, essentially the same as that in $4: 3,8{ }^{66}$ If so, his rebellion was more precious than his life. ${ }^{67}$ However, the fact that Jonah prays in 2:2 [ET 1] suggests that death did not remain his ultimate ideal. ${ }^{68}$ Perhaps the shift happened earlier? If so, Jonah through his own voluntary self-offering is willing to ensure justice for the 'innocent' heathen sailors. At any rate, he did not want the sailors to die with him. ${ }^{69}$ The book of Jonah is not written to combat a narrow nationalism personified in its chief protagonist. ${ }^{70}$

Death as undesirable for Jonah continues in the psalm itself. We hear Jonah's prayer of thanksgiving as he prays, safely harboured, from the stomach of the fish (2:2 [ET 2:1]). He looks back to his time in the depths of the sea as a time of 'distress' when he called 'from the belly

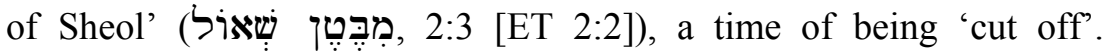
Deliverance for him consisted in YHWH bringing his life up from the pit (2:7 [ET 2:6]). What was for him an acceptable place is now a place from which he sought and welcomed deliverance.

In chapter 4, this changes backwards and forwards. The non-death of Nineveh provokes Jonah's ire and prompts a death-desiring outburst (4:3). A few narrative moments later, Jonah is keen for selfpreservation, building a 'shelter', delighting in a shade-giving plant. That ambivalence blossoms in 4:8. When his joy-bringing shade is destroyed and the dangerous sun beats down on him, there is an

65 E.g., Friedemann W. Golka, 'Jonah' in Revelation of God: A Commentary on the Books of the Song of Songs \& Jonah, Friedemann W. Golka and George A. F. Knight (Grand Rapids, MI: Eerdmans, 1988): 78.

66 Wolff, Obadiah \& Jonah, 118.

67 Simon, Jonah, 36.

68 George M. Landes, 'The Kergyma of the Book of Jonah', Interpretation 28 (1967): 22. Even if the psalm is regarded as secondary, the narrator's recording that Jonah prayed indicates that he did not accept his own death.

69 Simon (Jonah, xxi) speaks of Jonah's 'moral grandeur'.

70 Note in that regard that 'Israel' never occurs in the book; Nineveh is indicted for its wickedness, not as a foreign nation that has oppressed Israel. That is of course not to say that there is no significance to the contrast between Jonah the 'Hebrew' (1:9) and pagan sailors or Ninevites. 
identical death-desiring outburst. In fact, he is angry enough to die (4:9). His attitude to death for others remains constant. Death for the Ninevites is desirable, but for the sailors and the plant it is not. But his own death is both desirable and undesirable.

\subsubsection{Knowledge}

In his work The Poetics of Biblical Narrative, Meir Sternberg identifies three reading positions that the narrator gives the reader in relation to the characters: 'reader-elevating, character-elevating, and evenhanded'. ${ }^{71}$ These positions relate to the relative knowledge and perspective of characters and reader. In the opening chapter, the reader is clearly elevated above the characters. As Jonah heads off to Tarshish in the boat, the narrator tells the readers that YHWH hurled a great wind into the sea. The reader knows what the characters are not told. The sailors are furthest below the reader. In desperation, they try calling on their different deities to end the storm (1:5); to complement their piety, they hurl the raison d'être of their voyage into the sea; the captain heads down to the depths of the vessel and summons Jonah to call on his God (1:6). The sailors are not just ignorant about the stormbringer. They are also ignorant about the culprit, so they embark on a quintessentially Israelite lot-casting voyage of discovery, in their search to 'know' (ידעע) on whose account this evil is upon them. ${ }^{72}$ Throughout, the reader enjoys that sense of elevation above the sailors.

Jonah is below the readers, but above the sailors. At every point in chapter 1 , he is the source of knowledge and accurate information for them. His confessions of faith are exemplary. In response to the pummelling questions of the sailors, he declares that he is a Hebrew, and that it is YHWH, the God of heaven, who made the sea and the dry land, that he worships (1:9). In a parenthetical fashion that does not sully the purity of Jonah's confession with mere narrative detail, the narrator lets the readers know that the sailors 'knew' (ידעי) he was fleeing from YHWH, for he had told them (1:10). That sense of accurate knowledge extends to Jonah's 'knowing' (ידעע) that it is because of him that the storm is upon them (1:12). Jonah is the source of reliable information in his solution to the problem. Hurl him into the sea, and the storm will be quiet. And after their pious prayer, the sailors

71 Sternberg, Poetics, 163.

72 For the Israelite nature of lot-casting, see Brent A. Strawn, 'Jonah's Sailors and Their Lot Casting: A Rhetorical-Critical Observation', Bib 91, no. 1 (2010): 66-76. 
do just that and the storm duly ceases from its raging. The sailors knew nothing; Jonah knew some things about YHWH and about his own flight, so discerned the right course of action. The readers are elevated above both. They know what Jonah has deduced and what the sailors only discovered after frantic searching, desperate lot-casting and pressing questions.

But the reader is not exalted above the characters for ever. The king of Nineveh's proclamation, after calling for repentance, wonders, 'Who knows (ידעע)? God may relent and change his mind.' Readers do not know what God will do, either. Characters and reader are evenhanded for a moment. But Jonah had deduced it! He knows (ידעצ') YHWH's character-he knew it when he fled - and he had foreseen what would happen (4:2). Suddenly Jonah is elevated not just above the other characters, but above the reader, too. The narrator has fostered one way of seeing it, only to reverse it.

In so doing, knowledge, particularly Jonah's knowledge, is established. But there is a further twist. Knowledge alone is not enough. Jonah knew more and better than the other characters, but what he did with that knowledge was profoundly out of touch with YHWH. Furthermore, lack of knowledge is not a bar. As the book ends, YHWH declares that Nineveh has more than 120, 000 people in it who do not know (ידעע) their right from their left. This is probably not a reference to 'children', given their designation אָד (cf. 3:7-8). ${ }^{73}$ Whether it is a reference to a comparative inability to make moral judgements, ${ }^{74}$ or a 'relative lack of knowledge of God and his law', ${ }^{75}$ the Ninevites did not have the privilege of knowledge, yet responded in a way far surpassing Jonah.

\subsection{Structure}

Alongside the structural parallels that exist, Jonah 4, in particular, exhibits what Trible has dubbed 'symmetrophobia'. ${ }^{76}$ While there may be formal scenic correspondence with chapter 2, the final verses move beyond what has been seen before, and in challenging directions. There is the open-ended conclusion (vv. 10-11), where YHWH's engagement with Jonah gets no response. It is left to the reader to answer and to

\footnotetext{
73 Contra, e.g., Simon, Jonah, 47.

74 Wolff, Obadiah \& Jonah, 175.

75 Jenson, Obadiah, Jonah, Micah, 93.

76 Trible, Rhetorical Criticism, 117.
} 
ponder. ${ }^{77}$ The major plot complication of the book, Jonah's relationship to YHWH, receives no sense of closure, or, at least, no explicitly articulated sense of closure. But there are more undercurrents.

How do YHWH's words in verses 10-11 relate to Jonah's reaction to the plant? It looked from the preceding narrative as if Jonah's concern for the plant was self-interested rather than pitying, as YHWH said. Presumably the reader is meant to recognise in YHWH's pronouncement an accurate judgement, but the gap remains. ${ }^{78}$ Again, YHWH's statement about pitying Nineveh makes no reference to Nineveh's repentance or aspects of his character that Jonah has highlighted. There was no obligation on YHWH's part to relent from judgement, for 'pity' is not an attribute of YHWH's character. ${ }^{79}$ YHWH was not compelled to respond to repentance. Presumably the reader is again meant to recognise a continuity with $4: 2$ as well as ponder the difference, but the reader has to do the work.

Finally, verse 11 begins not with a syntactically marked question,

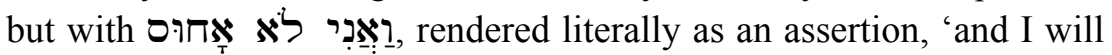
not have pity on'. Notwithstanding the LXX, which may follow the assertive rendering, ${ }^{80}$ and some recent interpreters, ${ }^{81}$ it almost certainly should be read as an unmarked rhetorical question. Hebrew syntax allows it, ${ }^{82}$ the incongruity of YHWH's non-sparing of people who do not know their right from their left demands it, and, as Ben Zvi puts it, 'the plot of the book of Jonah collapses without the salvation of Nineveh' ${ }^{83}$ On the other hand, Jonah went out of the city to see what would happen to the city, hinting at other possibilities. YHWH has been

77 Unless we interpret Jonah's silence as 'compliance' (so Simon, Jonah, 48).

78 Note in particular the creative argument of Barrett, 'Meaning More Than They Say', proposing that the argument is not an a fortiori one where Jonah-קיקיקיוֹ is analogous to YHWH-Nineveh, but that there is a two-step qal wahomer, whereby both point beyond themselves to YHWH's relationship with Israel (embodied in Jonah).

79 Cf. Terence E. Fretheim, 'Jonah and Theodicy', ZAW (1978): 231-33.

80 George E. Howard, 'The Twelve Prophets' in A New English Translation of the Septuagint: And the Other Greek Translations Traditionally Included Under That Title, ed. Albert Pietersma and Benjamin G. Wright (Oxford: Oxford University Press, 2007): 805 regards either rendering possible.

81 Alan Cooper, 'In Praise of Divine Caprice: The Significance of the Book of Jonah' in Among the Prophets: Language, Image and Structure in the Prophetic Writings, ed. P. R. Davies and D. J. A. Clines (JSOTSup, vol. 144; Sheffield: JSOT, 1993): 144-63; Philippe Guillaume, 'The End of Jonah is the Beginning of Wisdom', Bib 87 (2006): 243-50.

82 Cf. Kamp, Inner Worlds, 109 n. 39; JM §161a.

83 Ben Zvi, Signs of Jonah, 14. 
responsive to Jonah's initial flight and to the Ninevites. ${ }^{84}$ Perhaps YHWH might be responsive again? The plant to deliver Jonah from his 'evil/distress' was one that YHWH made great (like Nineveh) and then destroyed (like Nineveh?). Finally, for the readers, Nineveh lay in ruins. A 'double ending' for Jonah's readers is plausible. ${ }^{85}$

\section{The Purpose / Effect of Such Undercurrents}

Beneath the calm surface of the book of Jonah there are swirling undercurrents. In particular, it is in the very places where the water is calmest on the surface that undercurrents may be found.

The undercurrents in Jonah at one level have an aesthetic function; they give a depth to the book, and foster continual engagement with it. But there is also a didactic purpose. The repeated questions throughout the book cultivate readerly involvement and identification. What that purpose is has been much debated. ${ }^{86}$ That it has been hard to pin down is unsurprising, especially when a unitary purpose has been proposed. It is rather found in an interplay between what it means for YHWH to be YHWH, and what it means to engage with, or live in the light of, this god: how credal confessions relate to lived experience. Jonah's confessions serve as the exemplar of what to believe, for his knowledge has been proved accurate. Yet that knowledge has been shown to be inadequate. Alongside it is needed the responses the sailors and the Ninevites embodied. Together they exemplify the cultic response, of sacrifices and vows, and the moral response, of repentance, that Israel should embody. ${ }^{87}$ Herein lay hope and a challenge for YHWH's people. There was hope because even pagans could exemplify the right response such that YHWH heeded it. For an Israel at points in its history apparently cut off from the covenant by idolatry and wickedness, there could be a way back. Furthermore, YHWH did not cast Jonah (Israel) adrift, but relentlessly pursued and persuaded him.

\footnotetext{
84 Barrett, 'Meaning More Than They Say', 242.

85 Ben Zvi, Signs of Jonah, 28; Ehud Ben Zvi, 'Jonah 4:11 and the Metaprophetic Character of the Book of Jonah', JHS 9: Article 5 (2009). It is not a "superfluous exegetical toy" (Philippe Guillaume, "Rhetorical Reading Redundant: Response to Ehud Ben Zvi', JHS 9: Article 6 [2009]: 9).

86 For a recent concise and helpful appraisal of the 'message' of Jonah, see Jenson, Obadiah, Jonah, Micah, 36-40.

87 Cf. Barrett, 'Meaning More Than They Say', 257.
} 
And there was a challenge, because 'not even in Israel', not even in a paradigmatic Israelite prophet, had YHWH found the right response (cf. Luke 7:9). Instead, it was pagans who demonstrated the appropriate response to a deity whose character is declared and whose conduct is depicted in the distilled masterpiece that is the book of Jonah. 